Article

\title{
Grassroots and Global Governance: Can Global-Local Linkages Foster Food System Resilience for Small Northern Canadian Communities?
}

\author{
Carla Johnston ${ }^{1}\left[\right.$ and Andrew Spring ${ }^{2, *}$ (i) \\ 1 Balsillie School of International Affairs, Wilfrid Laurier University, Waterloo, ON N2L 6C2, Canada; \\ cjohnston@balsillieschool.ca \\ 2 Laurier Centre for Sustainable Food System, Wilfrid Laurier University, Waterloo, ON N2L 6C2, Canada \\ * Correspondence: aspring@wlu.ca
}

check for

updates

Citation: Johnston, C.; Spring, A. Grassroots and Global Governance: Can Global-Local Linkages Foster Food System Resilience for Small Northern Canadian Communities?. Sustainability 2021, 13, 2415. https://doi.org/10.3390/su13042415

Received: 25 January 2021

Accepted: 18 February 2021

Published: 23 February 2021

Publisher's Note: MDPI stays neutral with regard to jurisdictional claims in published maps and institutional affiliations.

Copyright: (c) 2021 by the authors. Licensee MDPI, Basel, Switzerland. This article is an open access article distributed under the terms and conditions of the Creative Commons Attribution (CC BY) license (https:// creativecommons.org/licenses/by/ $4.0 /)$.

\begin{abstract}
Communities in Canada's Northwest Territories (NWT) are at the forefront of the global climate emergency. Yet, they are not passive victims; local-level programs are being implemented across the region to maintain livelihoods and promote adaptation. At the same time, there is a recent call within global governance literature to pay attention to how global policy is implemented and affecting people on the ground. Thinking about these two processes, we ask the question: (how) can global governance assist northern Indigenous communities in Canada in reaching their goals of adapting their food systems to climate change? To answer this question, we argue for a "community needs" approach when engaging in global governance literature and practice, which puts community priorities and decision-making first. As part of a collaborative research partnership, we highlight the experiences of Ka'a'gee Tu First Nation, located in Kakisa, NWT, Canada. We include their successes of engaging in global network building and the systemic roadblock of lack of formal land tenure. Moreover, we analyze potential opportunities for this community to engage with global governance instruments and continue connecting to global networks that further their goals related to climate change adaptation and food sovereignty.
\end{abstract}

Keywords: global governance; food systems; climate change; adaptation; knowledge sharing; community-needs approach; Indigenous; northern Canada

\section{Introduction}

Indigenous and traditional food systems across the world are under threat due to pressures of globalization and industrial food production practices. Rising rates of food insecurity, particularly in remote communities, are compounded by ecological stresses due to climate change and further threatened due to the impacts of the pandemic [1-4]. For the most part, our global food system will continue to function so that those that already can afford and have consistent access to food will continue to be food secure, as the current global food system will adapt, more or less, to climate change through efficiencies, technologies, and policies [5,6]. It is the regions and communities that are currently on the margins of the food system, either those living in subsistence-based systems, those closely tied to the land, or those already living in poverty-stricken areas, that will be the most impacted by climate change and food insecurity [7-9].

Canada's North is at the forefront of global climate change. Parts of northern Canada have seen an increase in temperature of roughly four to five times greater than the global average; ecosystem form and function are being dramatically changed in a relatively short period of time [10]. Permafrost thaw, degrading sea ice conditions, changing migratory patterns of animals, increased intensity and frequency of wildfire, and changes in water availability are impacting the region. These impacts are projected to continue to intensify in the future $[10,11]$ with direct and often negative implications for the ability of individuals 
and communities to hunt and gather traditional foods. Climate change is making it more difficult to maintain traditional ways of life, reducing both the availability and accessibility of traditional food [10,12-17]. Despite these challenges, Indigenous peoples in northern Canada are not passive victims of climate change; they are adapting through everyday adjustments to continue their traditional practices and taking on innovative projects that build their knowledge and foster new actions. As such, there is a wealth of knowledge and experience in communities across the North on adapting to the impacts of climate change. These community-scale adaptations have been shown to be successful at reducing vulnerability [18] while also providing lessons to other communities [19]. This bottom-up approach supports Indigenous conceptions of food sovereignty, where Indigenous peoples frame their own food security [20] and re-establish respectful relationships with land, water, and wildlife in ways that allow for mutual benefit [21-23].

While community-based actions are fundamental to Indigenous food sovereignty and adapting food systems to climate change, there are systemic issues that affect Indigenous communities in northern Canada that are challenging to address at the community-level alone. Highlighting the failure at multiple scales to support resilient northern food systems, households in Canada's northern communities have reported rates of moderate to severe food insecurity ranging from $17 \%$ to $69 \%$, dramatically higher than the national average of $8 \%$ [24-26]. These food insecurity rates in northern Indigenous communities are the highest of any Indigenous population in a developed country [27]. Part of this challenge includes the historic and continued colonial systems that have exerted pressure on Indigenous communities for generations, undermining self-determination and way of life [28,29]. In connection, northern Indigenous food systems depend on access to land, resource rights, and ecosystem health, so they are also deeply connected to the politics of development and globalization [30-33]. Furthermore, issues of remoteness, lack of economic opportunities, and infrastructure compound food insecurity [25]. These and other social, economic, and political issues shape food system challenges in the North, altering the intergenerational relationship that Indigenous communities have with the land and impacting overall health and well-being [7,25,34,35].

These systemic issues that intertwine with climate change and affect food systemsland and resource rights, lack of supportive governance, development pressures, limited local capacity-also play out in different contexts around the world [36]. Seeking to bring recognition to and address these issues, Indigenous and civil society activists bring their experiences to the global scale by engaging in transnational social movements and advocating in global governance spaces (there is a difference between non-profit civil society and corporate sector associations. Further, there is a difference between civil society that advocates for or provides emergency and development assistance to marginalized peoples, and civil society that is made up of and speak on behalf of people that directly participate in the activities that are being debated. In this paper, the use of "civil society" regularly refers to the latter category [37].). These efforts take many forms including the protests and counter-events outside of global summits, Indigenous peoples and smallscale farmers making interventions on plenary floors of international meetings, high-level human rights petitions, and being directly included in debates and policy formation in select global institutions [38-42]. With so much activity and many similar struggles among advocates, could there be opportunities within global governance to make an impact on the systemic issues and further the goals of northern Indigenous communities in Canada?

In this paper, we highlight the experiences of Ka'a'gee Tu First Nation (KTFN), located in Kakisa, Northwest Territories (NWT), Canada, adapting their food system to climate change. We include their priorities, successes, and the systemic roadblocks they encounter. As part of an ongoing partnership with the KTFN, this paper is an analysis of literature and empirical examples relating to potential opportunities for this small northern community to engage with global governance instruments and connect to global networks to further their goals related to climate change adaptation and food sovereignty. Therefore, in this paper we ask the following question, (how) can global governance assist KTFN in reaching 
their goals of adapting their food systems to climate change? To begin answering this question, we lay out a "community needs" approach to engaging in global governance literature and practice, which highlights the importance of putting community priorities and decision-making first. Next, we provide context about Kakisa and the climate change adaptations that are happening in the community. With this context in mind, the following two sections of the paper highlight areas of priority for KTFN, along with potential opportunities to engage globally. First, they want to increase protection and care for their traditional territories, however, they lack formal land tenure. Second, KTFN is experimenting with small-scale agriculture that sustains the local ecosystem, yet this is a new endeavor for the community with various challenges described below. Through an analysis of various opportunities at the global level relating to these two goals, we see solidarity and relationship-building through global networks, as well as using global frameworks to enhance community-based actions as potentially promising ways that engaging in global governance could assist KTFN.

\section{2. "Community Needs" Approach to Engaging in Global Governance}

In this paper, we examine the question of (how) global governance can assist KTFN in reaching their goals of adapting their food system to climate change. This question is rooted in the theoretical perspectives of critical Indigenous literature that places an emphasis on the needs and aims of communities [43-45]. In particular, scholars focus on "being Indigenous" [44] as one of the strongest forms of community resilience and resistance to colonial forces. This includes living out all aspects of Indigenous ontologies in the everyday life, from their land-based food systems to their interconnected forms of governance and self-determination [46-48]. The community level is significant to this approach because this is where relationships between people, land, and ecologies are often most closely connected. This further connects with the concept of "epistemologies of the south" ("south" here does not refer to the geographical global south but to othered, non-dominant ways of being) [49] that highlights the failings of Eurocentric societies to acknowledge other ways of knowing and being as valid. Indigenous ways of life that are biocentric and relational to past and future generations, the environment, and well-being are often one of these epistemologies of the south that have been and continue to be othered. As de Sousa Santos (2018) [49] writes, "such destruction disempowered these [othered] societies, rendering them incapable of representing the world as their own in their own terms, and thus of considering the world as susceptible to being changed by their own power for their own objectives" (p. 8). It is the heterogeneity and non-hierarchical nature of societies, including the power and objectives of the KTFN community that we seek to highlight. It is important to note that following a community's own objectives can take many forms. Some scholars illuminate the importance of Indigenous communities disengaging with state-based structures [29,47], while others show how they work with states as a means to enliven and further their own governance systems [45,50]. It is the needs and goals of communities, in their own articulation, that is significant.

This community-driven perspective also builds on the theoretical literature of procedural justice for othered communities [51-54] and further studies that highlight the importance of democratic participation in political processes in global food governance [55-57]. This literature notes how a lack of respect and recognition of othered groups in social spaces is connected to their ability to participate in political processes, which reinforces discrimination and marginalization. In practice, this is connected to demands for "a seat at the table" and community participation in policy-making by civil society groups, and Indigenous peoples' call for self-determination. Yet, the above critical literature on community needs can nuance these demands slightly. It helps us to recognize that some communities may not desire, or be able to hold that seat at the table for various reasons connected to their own visions, priorities, and decision-making processes. This does not necessarily mean that those communities do not value participatory policy-making, but that their community needs may mean pursuing other forms of actions. 
We also draw on methodological practices centered on critical Indigenous thought. In particular, Gaudry (2011) [43] calls for "recenter[ing] the community in the research process (1) by explicitly employing Indigenous worldviews; (2) by orienting knowledge creation toward Indigenous peoples and their communities; and (3) by seeing our responsibility as researchers as directed almost exclusively toward the community and participants" (p. 114). This approach is a counterpoint to what Gaudry (2011) [43] explains as "extractive research". Extractive processes, "take deeply meaningful information, often from a marginal or 'underresearched' community, and presents it to a third party. This third party is usually a highly educated academic audience or government bureaucracy, both of whom have little staked on the preservation of the integrity of that extracted knowledge. Lost in this extractive process are the context, values, and on-the-ground struggles of the peoples and communities that provide that information and insight to the researcher" (p. 113). While this is an article aimed at global governance scholars, it is the context, values, and on-the-ground struggles of adapting KFTN's food system to climate change that takes center stage. Furthermore, this paper, written near the beginning of engaging with KTFN on global endeavors, is part of the process of working with them to think through the opportunities and challenges of engaging in global governance. By illuminating this methodological and praxis-driven process throughout the paper, we also speak to other communities that have experienced or may be considering navigating global governance structures.

In terms of the methods for this paper, we draw on previous participatory action research (PAR) with KTFN, participant observation at the UN Committee on World Food Security (CFS), and a review of literature on Indigenous involvement in global governance forums. Concurrently, the authors are engaged in community-led climate change adaption planning with KTFN, which has allowed members to express their visions and priorities for their community. It also assists the authors in analyzing and presenting the information in this paper. Furthermore, the ideas in this paper are being discussed with the community, and ultimately, they will decide how to proceed and what options fit their needs and interests, as continues to be the foundation of our collaborative work together. In connection, PAR is central in our "community needs" approach, ensuring research is community-driven and responds to their practical concerns through the active collaboration of researchers and participants $[58,59]$. Fundamental to the work conducted in northern communities is building trust-based relationships by fostering opportunities to spend time together, often on the land, being flexible, and creating opportunities to involve communities in all aspects of the research process [60-62]. This approach also helps to foster a "two-eyed seeing" approach that emphasizes both traditional and western knowledge and research methodologies $[63,64]$. In this way, PAR embodies the "collaborative entanglement" understanding of knowledge mobilization and highlights how knowledge is co-created and shared in purposeful ways to achieve the common goal of increasing food system resilience within, among, and beyond participant communities. It is strong trust-based relationships that can create the iterative cycle of knowledge creation, community action, and reflection.

Bringing the above theoretical and methodological approaches together, we refer to these community-centered perspectives as a "community needs" approach. We use this approach as a guide to exploring the potential opportunities and barriers of KTFN engaging in the processes of building global solidarity and knowledge exchange, as well as global policy-making and operationalization. Yet, global governance literature and practice can be an "extractive" space, and community aims are rarely the focus of analysis or responsibility. Much of the literature is focused on understanding and improving upon the practices that exercise global authority. In their synthesis and future-looking paper on the field of global governance, Coen and Pegram [65] note that while there have been many disciplinary, empirical, and theoretical openings in the literature, the gaze remains within the realm of global politics. As they explain, when thinking about scale and different levels of governance, it is regularly with the top-down view of implementation and policy delivery. When paying attention to upward processes, such as non-state actors' participation and the 
motives of various stakeholders, most literature seeks to understand how this affects global governance outcomes. One area of the broadening empirical base in the field includes Weiss and Wilkinson's [66] call for examining "everyday global governance," or how people on the ground receive, experience, and encounter global governance. As community-based researchers, we welcome this call to engage with communities on their perceptions and connections to global governance, yet this approach continues to funnel experiences into understanding and improving upon global policy processes. For example, they conclude that "looking up at global governance from the point of view of those who are governed" will help us understand "most importantly, what kind of global governance that we ought to have" [66]. Here, the needs and goals of communities that are engaged are not the primary focus of the research, they are a means to an end.

It is not the aim here to discredit work within the field of global governance; it is simply to highlight their centers of focus and responsibility and what intellectual blinders this can create [67]. Of course, working to improve global policy structures will no doubt have positive effects, especially for the community-based activists and advocates that engage in those spaces $[55,56,68]$. However, the primacy of focusing on understanding and improving global governance can limit what we decide is relevant for analysis when engaging with people on the ground and their connections to global governance. This can risk losing sight of what is meaningful to the people that one is researching with. In contrast, through the lens of community needs and goals, the way we look at global governance changes and broadens in scope. For example, it leads us to ask questions about if the global level is the most effective space to address the challenges a community faces or reach its goals. Are there costs to the community by participating in global processes or research about global governance? How have grassroots movements used global governance products and processes to meet their needs and goals? (How) does a community's needs fit within various global norms and policies? (How) can participation in global governance practice and research enhance community resilience, culture, and way of life? In this paper, we partially explore these questions in our narratives and analyses. Importantly, the broadened scope of questions relating to community needs may well have insights for understanding and improving upon global governance, however, it is the responsibility to communities and their needs that comes first in the research and knowledge creation.

In the practice of global governance, there are food movements that align with a community needs approach. In particular, the food sovereignty movement, originating with La Via Campesina (LVC), is rooted in the local food system struggles of peasants, Indigenous peoples, farmworkers, land-less peasants, fisherfolk, consumers, women, and young people [69]. Food sovereignty is an alternative food system paradigm that rejects the mainstream neoliberal industrial food system for one that upholds "the right of peoples to healthy and culturally appropriate food produced through ecologically sound and sustainable methods, and their right to define their own food and agriculture systems" [70]. Ultimately, food sovereignty is about increasing democracy, ecological sustainability, biocultural diversity, and social justice in our global food system through localized, contextspecific actions $[37,71]$. Increasing the importance of place-based control, Indigenous food sovereignty emphasizes self-determination of traditional lands and food systems [72]. LVC members note that the movement was born out of the need for voices from the ground to be brought into global debates on food systems [73,74]. Quoting an LVC member, Gaarde [75] highlights the importance of being rooted in the community when engaging in global governance.

"We maintain the visibility of local struggles globally and at the same time highlight the global aspects in local struggles. This is even more important in our efforts to build alternatives, as we are building ecological alternatives and food sovereignty that start from local action and are solutions to global problems" (p. 10, quoting LVC member).

There are important connections between local realities and global structures and policies. Yet, the food sovereignty movement sees the focus of action and responsibility to be at the 
local level first, similar to the community-needs approach we argue for. Therefore, in the context of Kakisa, a community-needs approach that connects to the food sovereignty movement makes us ask different questions when engaging at the global level. As we will expand below, we ask about the opportunities for knowledge-sharing and solidaritybuilding in global governance spaces. Are there possibilities of circumventing gridlocked land governance processes at the territorial and national level that are impeding local and regional food sovereignty and climate change adaptation initiatives?

\section{Case Study: Climate Change Adaptation in Kakisa, NWT}

The small Indigenous community of Kakisa is located in the Dehcho region of Canada's NWT. This Dene community of approximately 50 people continues to rely on the traditional food system of harvesting, fishing, and gathering of foods from the lands, lakes and rivers of the surrounding boreal forest. Community members support their livelihoods through the traditional economy, commercial fishing, and limited employment opportunities available through the Band Office. For most, other employment and services, including grocery stores, are accessible in other communities, often requiring travel of up to $300 \mathrm{~km}$ (round trip). Climate change adaptation and food security planning research started in Kakisa in 2013 due to community-identified threats of climate change to the traditional food system and health of the community [17]. Community members have witnessed changes in water resources, ice conditions, permafrost and land subsidence, health and behavior of traditional food species, and weather patterns $[17,61]$. The impacts of forest fires, which directly affected the community in the summer of 2014, causing the evacuation of the town, are of particular importance. There has been an increase in the severity and intensity of fires, which has led to community questions regarding the ongoing impacts on forest regeneration, access to land, and the return of important traditional food species [49]. These changes on the land have resulted in more time and resources being needed to access traditional foods and an increased risk to harvesters' safety due to uncertain and unpredictable terrain and weather patterns. The community, however, continues to adapt to these changes and build resilience into its food system. Much of their continued adaptation is due to their strong cultural and social ties within the community, where traditional knowledge and connection to the land play a key role. However, there are some key limitations to adaptation, specifically, where traditional knowledge cannot keep up with the dramatic rate of change being observed on the land [76].

With such a small population, there are limits to community capacity to answer some of the questions the community has regarding changes to the land and its impact on the food system. The community has therefore built strong, long-term relationships with university and government researchers, including the authors of this paper, to address some of these issues. Community-based projects have developed over the years to incorporate growing food, waste management, on-the-land learning that focuses on inter-generational knowledge transfer, and other environmental research and monitoring initiatives $[17,61,62,77]$. There is a great deal of work going on that has led to employment opportunities, improved community engagement and participation, and a sense of pride in their accomplishments. Certainly, this has been a good model of how community-research relationships can foster climate change adaptation, planning, and action [62], and communities can look to Kakisa as a source of inspiration and leadership for the impact even the smallest communities can have. However, it should be noted that many of these initiatives represent projects that required a small bit of capacity and funding, the low hanging fruit, as opposed to larger, more complex issues fundamental to shifts in the community's food system.

One of the challenges that KTFN faces is that they do not have formal tenure of their traditional lands. Protection of their traditional territory and enhanced decision-making over issues that impact the land and people is seen as a key step by KTFN in securing the community's food system [17]. In 1999, the Dehcho First Nations (DFN), the regional Indigenous governing body that Kakisa is a part of, started negotiating a comprehensive land claim with the federal government. This process has stalled many times over the 
past two decades as there continues to be a wide gap between the positions of the federal government and the DFN on the issues of lands and resource management [78]. In an attempt to move the process forward, in 2019, the DFN requested a sectioned approach that puts lands and resource negotiations aside for now and focuses on self-government discussions including education, health, and governance [78,79]. Therefore, it may take quite some time before this land claim process is settled. In another effort to gain protection and more control of their lands, KTFN participated in the Government of Northwest Territories (GNWT)'s Protected Areas Strategy process, which outlines conservation network planning in the NWT. As part of this process, an area of $9600 \mathrm{~km}^{2}$ around Kakisa is set as a candidate area for a future protected area. Unfortunately, this process has also stalled, with no significant progress since 2012 when the GNWT withdrew from the process [79]. The lack of direct control of their lands, due to these stymied processes, creates challenges in KTFN's traditional food system and the adaptations the community can pursue. As an example, the community has been interested in experimenting with developing a smallscale farm in a planned fire break, aimed at protecting the community from future wildfire. However, jurisdictional issues are slowing the process of creating the fire break, as regional and territorial permits are needed to use the land for agriculture. In another example, protecting the land and waters to safeguard the subsistence and commercial fisheries that the community depends on is critical when considering plans to revitalize the fishing industry in the NWT [80]. Again, community concerns about protecting the KTFN's traditional territory and food system in the face of outside development and regulatory forces highlight the need for capacity and tools to be part of the dialog and contribute to the decision-making process $[61,80]$. Given the extended impasse that Kakisa faces around formal land tenure and that local control of their lands is a key priority for the community, we consider opportunities to circumvent this gridlock through global governance instruments and networks.

\section{Pressure from Above: Using Global Instruments to Address Systemic Issues}

There are theoretical and empirical examples of Indigenous peoples and civil society advocates sidestepping local blockages by engaging with global actors and institutions. Theoretically, this has been best captured through Keck and Sikkink's [81] "boomerang pattern" from the human rights activism literature. It is an explanatory model that highlights how domestic non-governmental organizations (NGOs) in global south countries that are unable to stop their national governments from committing human rights violations turn to international NGOs for assistance. These international NGOs work with global north states and global institutions to put pressure on the global south government to stop the violations. This tactic can be effective because the global south country often needs aid from those that are pressuring them [82]. While this model does not fit perfectly with Kakisa's context, being in a global north country, it does confirm how the power of national and other levels of government are permeable through globalized efforts [83]. In particular, the nation-state is not the only place for political engagement in our globalized world. Actors can engage on issues within global institutions or networks that have authority and/or influence over states. Furthermore, when actors engage in these spaces, they can encounter new norms, framings for arguments, and forms of action that may enhance their efforts back home $[84,85]$. As such, the boomerang pattern's general idea of creating pressure from above through globalized networks to affect government actions or create a more favourable environment for efforts at home could be useful to the community.

In practice, there are many ways that Indigenous peoples and civil society actors seek to create pressure from above. First, they use formal human rights petitions against states. For instance, Indigenous peoples in Canada have brought several petitions to the Inter-American Commission on Human Rights. In 2005, the Inuit Circumpolar Council (ICC) led by prominent Inuit activist Sheila Watt-Cloutier petitioned to investigate and sought damages due to the United States' contributions to climate change and their failure to take adequate mitigation measures. The petition was ultimately rejected, however, it has 
opened the door for similar cases, such as the pending petition by the Arctic Athabaskan Council (which formally represents KTFN as part of the broader Athabaskan peoples across the NWT, Yukon, and Alaska) against Canada on black carbon brought forth in 2013 [41,86]. In a different issue area, a case was brought to the Inter-American Commission in 2009 by the Hul'qumi'num Treaty Group against Canada to rule on the merits of recognizing Indigenous peoples' rights on private property. Despite being with the Commission for 11 years, no findings have been made [87]. Looking at these cases together, they have all brought significant awareness to the challenges Indigenous people in Canada face regarding the interconnected issues of land, food systems, and climate change. However, they have been lengthy and costly endeavors for minimal results or continued stalemate. In thinking about how global governance could assist Kakisa, a formal human rights complaint could be unsustainable, but knowledge of these cases can be part of a broader framework for action.

Another way that Indigenous peoples and civil society actors create pressure from above is by participating within global institutions, such as the United Nations (UN), to bring awareness to the issues affecting their communities and shape global norms and policy outcomes. Importantly, the various bodies within the UN have different structures for participation. Some past processes have allowed Indigenous peoples to be directly involved in debates and policy-making, such as the creation of the United Nations Declaration on the Rights of Indigenous Peoples (UNDRIP) [38], the UN Convention on Biological Diversity, and its Nagoya Protocol [40,88,89], and the International Labor Organization's Convention C169 [38]. Currently, the UN Committee on World Food Security (CFS) is considered the "foremost inclusive international and intergovernmental platform" [90] due to its Civil Society and Indigenous Peoples' Mechanism (CSM) and Private Sector Mechanism that are included in all policy-making processes, except for voting [44-46]. In other UN bodies, Indigenous peoples have less decision-making power. The Permanent Forum on Indigenous Issues is a subsidiary of the UN General Assembly, yet this space is limited to an advisory role [91]. Furthermore, the United Nations Framework Convention on Climate Change (UNFCCC) and UN Conference on Sustainable Development, the main bodies that discuss climate change, have been criticized for lacking Indigenous involvement until recently $[92,93]$. Indigenous peoples are now considered a "Major Group" of civil society in these processes, but it is still only states in the plenary hall making policies [94]. Given this varied landscape, it is important to think about which spaces allow for the most influence in decision-making. As such, we do see possible opportunities in connecting KTFN with the CFS and its corresponding CSM, particularly due to the prominence and respect for Indigenous peoples' participation, its focus on food systems, and the fact that one of the authors has experience with this forum. However, potential engagement does come with important considerations.

Even when Indigenous people are able to participate actively in UN institutions, such as the CFS, there are power dynamics to be aware of. In particular, the UN system is based on the voting power of states that can benefit from the control of resources and be invested in the structures that Indigenous peoples are seeking to change [38,87,95]. Furthermore, corporations are also actively engaged in UN institutions and the primacy of their bottom lines, increasing concentration and control of technology through intellectual property can create a very different set of priorities than those of civil society and Indigenous peoples $[96,97]$. While corporations do not have voting status, their power is significant due to their access and control of financial resources and the mainstream neoliberal political economy that caters to business interests $[56,98,99]$. Another layer of power is that UN bodies have their own, at times opaque, procedures and requirements that one must learn to navigate to participate meaningfully $[55,75,91]$. UN processes and structures are also based on Eurocentric constructions of politics, which can leave little room for other ontologies, such as Indigenous biocentric governance, to be valued, expressed, and incorporated. These power dynamics are important to be aware of when participating in a UN institution 
and when using their policy instruments; they are a product of the power structures at the time of writing.

Another consideration is that the time and resources it takes to participate in advocacy work within the UN system can be significant and put a strain on an already limited capacity. Quoting a La Via Campesina (LVC) member, Gaarde [75] highlights the following experience:

"It is harvest time at home these days. I need to plan and talk to my family on the phone to be sure my tomatoes are harvested. I am a food producer. It is a sacrifice for me to be here [at the CFS]. We are different from NGOs and other kinds of 'staff' who are paid for this work. For me as a farmer it is a cost to be away from my farm. It can sometimes look contradictory that I use so much time in Rome talking about agriculture and then leave my work on the farm behind. I constantly need to justify it to my colleagues that I am doing this kind of work" (p. 111).

While these sacrifices are significant, another LVC member explains why they put up with all of the challenges that come with engaging in a global institution.

"Being a social movement activist is the same all over the world: your commitment to the cause comes at a personal and financial cost. But the hard work needs to be done. Once we have decided to occupy a policy space we must be well organised and arrive to the negotiation table with well-deliberated contributions and solutions. We have a responsibility vis-à-vis other members to work for positive social change on the ground". (Gaarde, quoting an LVC member, p. 111, 2017) [75]

Part of what brings civil society actors to this work is the ability to influence global policy that can address the issues that they and their community experience. While this is important work, given this demanding context, we recognize that it could be quite challenging for KTFN to become a full advocate in a global institution. The time and resources this could take is significant for a community with already limited capacity. Of course, in line with our "community needs" approach, this is ultimately KTFN's decision based on their priorities, and the authors would be supportive of their participation.

There are examples of creating pressure from above, without the need to be a full advocate in a global institution, by using existing global policy instruments to assist activities at the ground level. This approach has been used by other civil society actors around the world. Franco and Suárez [100] discuss how actors in sub-Saharan Africa are embracing the Voluntary Guidelines on the Responsible Governance of Tenure of Land, Fisheries, and Forests in the Context of National Food Security (VGGTs) created through the CFS. They are using the VGGTs to shift the terrain of discussions about their land rights with states and other actors by framing their arguments around the guidelines and using them as a source of empowerment. This approach of using global frameworks to shift discussions and support community-based action could also be used by KTFN within their own context. Importantly, the VGGTs, which "set out principles and internationally accepted standards for practices for the responsible governance of tenure" [101] connect with KTFN's challenges around land tenure. Furthermore, the intergovernmental policy creation process for the VGGTs included significant participation by civil society and Indigenous peoples through the CSM. As such, the guidelines are seen as an instrument upholding human rights, with a particular focus on the rights of the vulnerable and marginalized [102]. Another potential opportunity to connect to global policy instruments relating to land and Indigenous peoples' rights is through UNDRIP. The GNWT has made it part of its mandate to implement UNDRIP by "[working] with Indigenous governments to create and implement an action plan that identifies changes required in GNWT legislation and policies to best reflect the principles set out in UNDRIP" [79]. The Canadian government has also recently introduced a bill to implement UNDRIP [103]. Because UNDRIP promotes Indigenous self-determination and control over 
traditional lands, it could also be a useful framework for KTFN. Whatever global policy instruments KTFN connects with, their use within the community itself can be significant. Considering the community prioritizes autonomy and self-sufficiency, the instruments could be used to strengthen grant applications for community-based actions, create better terrain for working with government and corporate actors, and increase general capacity from the knowledge of their rights and international principles related to the issues they face. This could create pressure from above by engaging with global frameworks using a "community needs" approach to strengthen actions and address the systemic issue of land tenure. In the following section, we turn to another opportunity of engaging in global governance for solidarity and knowledge-sharing.

\section{Solidarity and Knowledge Sharing through Global Networks}

Kakisa has a wealth of knowledge and experience working with groups and networks that support their vision for land stewardship and sustainable food systems [61]. In this section, we consider growing KTFN's networks to become more connected to the global food sovereignty movement, where many others are experiencing similar challenges and creating solutions. First, we highlight part of Kakisa's own experience in global network building and the importance that solidarity and knowledge-sharing have played. KTFN's networks extend to include international partners, including participating in research meetings with community partners from Brazil, Mexico, and Kenya. Often striking about those conversations with partners from around the globe are the similarities of climate change impacts on food systems (drought, as an example, threatens crops in Africa and access to traditional food in the NWT). One key area that Kakisa has prioritized is looking for assistance and knowledge about growing food and small-scale agriculture. As climate change continues to impact food systems in the NWT, there may be more opportunities for local food production, as temperatures warm and ecosystems shift [104]. Developing agricultural opportunities can work to alleviate some of the complex issues surrounding elevated levels of food insecurity in the NWT and build community resilience in the face of global threats. However, many important barriers exist that may limit the ability of communities to adapt and take advantage of this opportunity, including land suitability and availability, local capacity, limits to plant productivity, and lack of suitable policy and government assistance.

For Kakisa, ensuring that agriculture is developed in a way that meets the needs of residents without diminishing the overall health of the ecosystem or their traditional food system, is important. At the same time, growing food is not a component of the traditional knowledge system that exists in many northern Indigenous communities, and in fact, can be negatively associated with residential schools (from the 1880s to the 1990s, residential schools were run by the Canadian government and administered by churches with the explicit objective of assimilating Indigenous children into Euro-Canadian society and Christian ways of living. The system forcibly separated children from their families for extended periods of time and forbade them to practice their Indigenous culture or speak their own languages. Former students have spoken of horrendous physical, sexual, emotional, and psychological abuse at residential schools) [61,77]. KTFN has struggled to implement food-growing projects that have a meaningful impact on the local food system. As the community continues to advance food growing projects, questions about how to have more local engagement and ownership of food growing initiatives continue. This has raised questions in the community about how agriculture is being implemented in the NWT, and if there are better ways of grounding food growing in community knowledge and culture systems.

The opportunity to learn from other communities and regions where agriculture practices are part of a traditional food system, particularly those systems that prioritize land stewardship has been appealing to KTFN. In the fall of 2019, Chief Chicot of the KTFN travelled with researchers to Brazil to attend an agroecology workshop, tour local farms, and present at the International Union of Forest Research Organization 2019 
conference. Southern Brazil has been the site of a longstanding research network that connects across Canada and to Kakisa through several research grants. Some of the background of this trip is provided in Blay-Palmer et al. (2020) in the context of the right to food and Indigenous and traditional food systems. In southern Brazil, a long tradition of family farming persists with small-scale farms supplying approximately $70 \%$ of food to the domestic market [105]. Many of these farms use traditional agroforestry systems of food crops, vegetable gardens, non-wood forest products such as erva-mate, native fruits, and livestock grazing. These systems are both critical to the farms' income and food security $[106,107]$. These traditional agroforestry systems that have developed over generations, with roots in the Guaraní Indigenous knowledge, are now engrained in settler community food production practices [108]. As such, the relationship of these traditional producers to their land is intimately tied to their relationship to the forest and their roles as stewards and knowledge holders [109]. These food production methods and collective community action has resulted in the conservation and reforestation of $20-25 \%$ of the region's forest ecosystems and have had a profound impact on biodiversity and human livelihoods in the region $[1,110]$. During the trip, Chief Chicot and the researchers recognized that the Brazilian practitioners' knowledge about the intersection of food growing and forest management could be adapted to the NWT to help address the impact of climate change on the boreal forest, which is the basis of the traditional food system and an important global carbon sink. Furthermore, the linkages to Indigenous knowledge and some of the cultural similarities experienced on the trip helped the group to envision how aspects of the knowledge in Brazil could be applied, in some way, to Kakisa. However, the most important part of the entire experience was the welcoming and warm reception the visitor from the NWT received from the hosts and participants in Brazil. The time spent together learning and sharing knowledge and experiences formed relationships that helped mobilize knowledge to create new programming in the NWT. These exchanges have shaped and driven conversations in Kakisa about new ways of growing food, using the forest and traditional knowledge. The novel approaches being trialed in Kakisa are valuable to other communities as they speak to Indigenous participation and engagement in regional agriculture that may have policy implications as to how agriculture will develop in the North. This exchange is a prime example of the types of transformative knowledge sharing that can occur as a result of relationship and solidarity building.

Based on these initial beneficial experiences of knowledge-sharing and solidarity through global networks and KTFN's interest in this approach, we consider if there are similar opportunities at the CFS and food sovereignty movement within the CSM. Here, it is useful to provide a bit more background on what the CSM is as a global governance space. In response to the 2008 world food crisis, the CFS, which reports to the UN Food and Agriculture Organization (FAO), went through a reform process to create formal mechanisms for civil society and Indigenous peoples and the private sector to be included in all policy creation processes. This new inclusive structure came from a well-organized proposal from LVC and other civil society actors, who had been growing politically in the FAO and other international arenas since the 1990s. The CSM was established as an autonomous space for civil society to come together to discuss policy issues and create collective positions through their own perspectives and processes that are then brought to other members of the CFS $[42,75]$. This structure has allowed the CSM to become a formal space of agency and decision-making for civil society and Indigenous peoples, which is not seen in any other global institution. Furthermore, the CSM has also become a convening space based on solidarity that brings together food movement actors from all over the world. Solidarity is regularly referenced in relation to CSM actors having different histories and circumstances, but they work together across differences through a common goal for more just and sustainable food systems that support everyone, especially the most vulnerable $[57,111]$. Moreover, solidarity is also part of their normative framing of alternatives to the mainstream food system. Instead of the current neoliberal food system that caters to business interests and sees people as self-interested individuals, 
the movement calls for people to be considered rights holders that can care for each other and their local environments [73,112]. This context of autonomy and solidarity and the ability to meet many other actors experiencing similar food system challenges make the CSM a potentially fitting place for KTFN members to make connections from all over the world. Yet, as mentioned above, the issue of limited capacity could hinder the ability to fully engage in this global governance space. So, how can Kakisa connect to the knowledge and solidarity that the CSM brings together as well as share their own experiences?

Perhaps a way forward is to participate in knowledge-sharing Communities of Practice (CoPs) and networks that overlap with the more formal governance structures of the CFS and CSM. In terms of knowledge-sharing, the FAO has communities of practice (CoP) on agroecology (http:/ / www.fao.org/agroecology/communityofpractice/en/ (accessed on 10 January 2021)) and Indigenous peoples' food systems (http:/ / www.fao.org/indigenouspeoples/global-hub/en/ (accessed on 10 January 2021)). These CoPs include contributors from the CSM, in addition to policymakers, academics, and the private sector. Research findings, articles, reports, webinars, workshops, and other materials are shared through email listservs from the CoPs' various participants. There may be organizations that work on issues important to KTFN that they can connect to, helping to broaden their networks. Importantly, the knowledge gained through the CoPs can be incorporated into KTFN's community-based activities, and KTFN can also share their own experiences through these platforms. While these CoPs are technical and practical ways to connect to the knowledge flowing through the FAO more broadly, we also see potential connections through the trust-based relationships that KTFN has created within its research partnerships. Being part of a research network that has members who participate in the CSM can act as a bridge between spaces. As such, the partnership could help to bring knowledge from the CSM and discuss with community members if and how it connects to their priorities and actions. These connections can create new avenues and doors to be opened if the community would like to use them, similar to the opportunities created when Chief Chicot travelled to Brazil. Further, the trust-based relationships that are fundamental to a "community needs" approach could also assist KTFN when looking for options to create pressure from above as discussed in the previous section.

\section{Conclusions}

Grassroots movements have shaped global governance spaces and built international solidarity movements that can aid in local actions. This global space offers valuable opportunities to share knowledge and shape policy. However, there are considerable time and resource commitments required to be a part of these dialogs. For a small community such as Kakisa that is at the forefront of climate change impacts and is continuing to adapt and innovate its food system to support the health of the community, these spaces could still offer an opportunity to share knowledge and build support to overcome systemic barriers. Furthermore, because the regional land claim and local protected area strategy processes have stalled for KTFN, the potential of using global policy tools to overcome local and regional barriers could offer a breakthrough for addressing issues of land tenure and limited capacity. These global governance opportunities were analyzed using the community needs-based approach we argue for in this paper. This approach highlights the limitations of current global governance literature, which places an emphasis on understanding global policy outcomes and structures. Furthermore, the approach also challenges the typical understanding of how global and local connections can happen. Instead of linear paths flowing through formal local, federal, and global governance spaces, these pathways can be much more complex with communities able to work across scales. Yet, for many smaller communities, navigating these complex networks and relationships can be difficult. What has worked in Kakisa, thus far, has been built on relationships with a broad network of researchers and organizations that help to provide capacity and opportunity to be a part of peer-to-peer knowledge-sharing dialogs. Some of these opportunities, such as the trip to Brazil to learn about agroecology, have directly resulted in food systems innovation in 
the community. As these networks continue to grow and develop, they can intersect with other CoPs and networks that could provide the opportunity to join global governance dialogs, if it aligns with the vision and needs of the community. Like KTFN, there are other communities around the world that may be underrepresented in global policy and have limited ability to participate in global governance spaces. This paper helps to shed light on the process of navigating through the world of global governance in search of ways to ease the challenges these communities face and to have their communities' knowledge influence global policy. The opportunities that we have identified for KTFN will not fit in every context and are not prescriptive for other communities. It is through a "community needs" approach, which focuses on the goals and priorities of the community, that a variety of ways to engage in global governance can be found.

Author Contributions: Conceptualization, C.J. and A.S.; writing-original draft preparation, C.J. and A.S.; writing-review and editing, C.J. and A.S..; supervision, A.S.; All authors have read and agreed to the published version of the manuscript.

Funding: This research was funded by Social Science and Humanities Research Council (\#895-20151016) and through the Government of Canada's Climate Change Health Adaptation Program and Climate Change Preparedness in the North Program.

Conflicts of Interest: The authors declare no conflict of interest.

\section{References}

1. Blay-Palmer, A.; Spring, A.; Nimmo, E.; de Lacerda, A.E.B. Traditional Food, the Right to Food, and Sustainable Food Systems. In Routledge Handbook of Sustainable and Regenerative Food Systems; Duncan, J., Carolan, M., Wiskerke, J.S.C., Eds.; Routledge: London, UK, 2020. [CrossRef]

2. Bayha, M.; Spring, A. Response to COVID in Délınę, NT: Reconnecting with Our Community, Our Culture and Our Past after the Pandemic. Agric. Hum. Values 2020, 37, 597-598. [CrossRef]

3. UNFCC. United Nations Climate Change Annual Report 2019; UN Climate Change: Bonn, Germany, 2020.

4. FAO. Interim Issues Paper on the Impact of COVID-19 on Food Security and Nutrition (FSN). Available online: http://www.fao. org/fileadmin/user_upload/hlpe/COVID-19/HLPE._Impact_of_COVID-19_on_FSN_-_2020-03-24_-_EN4.pdf (accessed on 22 February 2021).

5. Howden, S.M.; Soussana, J.-F.; Tubiello, F.N.; Chhetri, N.; Dunlop, M.; Meinke, H. Adapting Agriculture to Climate Change. Proc. Natl. Acad. Sci. USA 2007, 104, 19691-19696. [CrossRef] [PubMed]

6. Ingram, J.S.; Gregory, P.J.; Izac, A.M. The Role of Agronomic Research in Climate Change and Food Security Policy. Agric. Ecosyst. Environ. 2008, 126, 4-12. [CrossRef]

7. Power, E.M. Conceptualizing Food Security for Aboriginal People in Canada. Can. J. Public Health 2008, 99, 95-97. [CrossRef] [PubMed]

8. Schmidhuber, J.; Tubiello, F.N. Global Food Security under Climate Change. Proc. Natl. Acad. Sci. USA 2007, 104, 19703-19708. [CrossRef]

9. Costello, A.; Abbas, M.; Allen, A.; Ball, S.; Bell, S.; Bellamy, R.; Friel, S.; Groce, N.; Johnson, A.; Kett, M.; et al. Managing the Health Effects of Climate Change. Lancet 2009, 373, 1693-1733. [CrossRef]

10. IPCC. Climate Change 2014: Impacts, Adaptation, and Vulnerability. Part. B: Regional Aspects. Contribution of Working Group II to the Fifth Assessment Report of the Intergovernmental Panel on Climate Change; Barros, V.R., Field, C.B., Dokken, D.J., Mastrandrea, M.D., Mach, K.J., Bilir, T.E., Chatterjee, M., Ebi, K.L., Estrada, Y.O., Genova, R.C., et al., Eds.; Cambridge University Press: Cambridge, UK; New York, NY, USA, 2014.

11. Price, D.T.; Alfaro, R.I.; Brown, K.J.; Flannigan, M.D.; Fleming, R.A.; Hogg, E.H.; Girardin, M.P.; Lakusta, T.; Johnston, M.; Mckenney, D.W.; et al. Anticipating the Consequences of Climate Change for Canada's Boreal Forest Ecosystems. Environ. Rev. 2013, 21, 322-365. [CrossRef]

12. Andrachuk, M.; Smit, B. Community-Based Vulnerability Assessment of Tuktoyaktuk, NWT, Canada to Environmental and Socio-Economic Changes. Reg. Environ. Chang. 2012, 12, 867-885. [CrossRef]

13. Ford, J.D.; Smit, B.; Wandel, J. Vulnerability to Climate Change in the Arctic: A Case Study from Arctic Bay, Canada. Glob. Environ. Chang. 2006, 16, 145-160. [CrossRef]

14. Ford, J.D.; Smit, B.; Wandel, J.; Allurut, M.; Shappa, K.; Ittusarjuat, H.; Qrunnut, K. Climate Change in the Arctic: Current and Future Vulnerability in Two Inuit Communities in Canada. Geogr. J. 2008, 174, 45-62. [CrossRef]

15. Pearce, T.; Smit, B.; Duerden, F.; Ford, J.D.; Goose, A.; Kataoyak, F. Inuit Vulnerability and Adaptive Capacity to Climate Change in Ulukhaktok, Northwest Territories, Canada. Polar Rec. 2009, 46, 157. [CrossRef]

16. Guyot, M.; Dickson, C.; Paci, C.; Furgal, C.; Chan, H.M. Local Observations of Climate Change and Impacts on Traditional Food Security in Two Northern Aboriginal Communities. Int. J. Circumpolar Health 2006, 65, 403-415. [CrossRef] 
17. Spring, A.; Carter, B.; Blay-Palmer, A. Climate Change, Community Capitals, and Food Security: Building a More Sustainable Food System in a Northern Canadian Boreal Community. Can. Food Stud. 2018, 5, 111-141. [CrossRef]

18. Ford, J.D.; Smit, B. A Framework for Assessing the Vulnerability of Communities in the Canadian Arctic to Risks Associated with Climate Change. Arctic 2004, 57, 389-400. [CrossRef]

19. Smit, B.; Wandel, J. Adaptation, Adaptive Capacity and Vulnerability. Glob. Environ. Chang. 2006, 16, 282-292. [CrossRef]

20. Rudolph, K.R.; McLachlan, S.M. Seeking Indigenous Food Sovereignty: Origins of and Responses to the Food Crisis in Northern Manitoba, Canada. Local Environ. 2013, 18, 1079-1098. [CrossRef]

21. Daigle, J.J.; Michelle, N.; Ranco, D.J.; Emery, M.R. Traditional Lifeways and Storytelling: Tools for Adaptation and Resilience to Ecosystem Change. Hum. Ecol. 2019, 47, 777-784. [CrossRef]

22. Kamal, A.G.; Linklater, R.; Thompson, S.; Dipple, J.; Ithinto Mechisowin Committee. A Recipe for Change: Reclamation of Indigenous Food Sovereignty in O-Pipon-Na-Piwin Cree Nation for Decolonization, Resource Sharing, and Cultural Restoration. Globalizations 2015, 12, 559-575. [CrossRef]

23. Lemke, S.; Delormier, T. Indigenous Peoples' Food Systems, Nutrition, and Gender: Conceptual and Methodological Considerations. Matern. Child. Nutr. 2017, 13, e12499. [CrossRef]

24. Rosol, R.; Huet, C.; Wood, M.; Lennie, C.; Osborne, G.; Egeland, G.M. Prevalence of Affirmative Responses to Questions of Food Insecurity: International Polar Year Inuit Health Survey, 2007-2008. Int. J. Circumpolar Health 2011, 70, 488-497. [CrossRef]

25. Council of Canadian Academies. Aboriginal Food Security in Northern Canada: An Assessment of the State of Knowledge; Council of Canadian Academies: Ottawa, ON, USA, 2014.

26. Tarasuk, V.; Mitchell, A.; Dachner, N. Household Food Insecurity in Canada, 2014. Available online: http:/ / proof.utoronto.ca/ (accessed on 27 August 2016).

27. Assembly, U.G. Report of the Special Rapporteur on the Right to Food, Olivier De Schutter; Human Rights Council: Geneva, Switzerland, 2012.

28. Sandlos, J. Hunters at the Margin: Native People and Wildlife Conservation in the Northwest. Territories; UBC Press: Vancouver, Canada, 2007.

29. Coulthard, G.S. Red Skin, White Masks: Rejecting the Colonial Politics of Recognition; University of Minnesota Press: Minneapolis, MN, USA, 2014.

30. Parlee, B.L.; Sandlos, J.; Natcher, D.C. Undermining Subsistence: Barren-Ground Caribou in a "Tragedy of Open Access". Sci. Adv. 2018, 4, e1701611. [CrossRef]

31. Blay-Palmer, A.; Knezevic, I.; Spring, A. Seeking Common Ground for Food System Transformation. Dialog-Hum. Geogr. 2014, 4, 185-189. [CrossRef]

32. Irlbacher-Fox, S. Finding Dahshaa: Self-Government, Social Suffering, and Aboriginal Policy in Canada; UBC Press: Vancouver, Canada, 2009.

33. Dokis, C.A. Where the Rivers Meet: Pipelines, Participatory Resource Management, and Aboriginal-State Realtions in the Northwest. Territories; UBC Pres: Vancouver, Canada, 2015.

34. Loring, P.A.; Gerlach, S.C. Food, Culture, and Human Health in Alaska: An Integrative Health Approach to Food Security. Environ. Sci. Policy 2009, 12, 466-478. [CrossRef]

35. Loring, P.A.; Gerlach, S.C. Searching for Progress on Food Security in the North American North: A Research Synthesis and Meta-Analysis of the Peer-Reviewed Literature. Arctic 2015, 68, 380. [CrossRef]

36. Blay-Palmer, A.; Sonnino, R.; Custot, J. A Food Politics of the Possible? Growing Sustainable Food Systems through Networks of Knowledge. Agric. Hum. Values 2016, 33, 27-43. [CrossRef]

37. Holt-Giménez, E.; Shattuck, A. Food Crises, Food Regimes and Food Movements: Rumblings of Reform or Tides of Transformation? J. Peasant. Stud. 2011, 38, 109-144. [CrossRef]

38. Scales of Governance and Indigenous Peoples' Rights; Bellier, I.; Hays, J. (Eds.) Routledge: Abingdon, UK, 2019.

39. Civil Society and Social Movements in Food System Governance; Andree, P.; Clark, J.; Levkoe, C.; Lowitt, K. (Eds.) Routledge: Abingdon, UK, 2019.

40. Teran, M.Y. The Nagoya Protocol and Indigenous Peoples. Int. Indig. Policy J. 2016, 7. [CrossRef]

41. Durfee, M.; Johnstone, R.L. Arctic Governance in a Changing World; Rowman \& Littlefield: Lanham, MD, USA, 2019.

42. McKeon, N. Food Security Governance: Empowering Communities, Regulating Corporations; Routledge: Abingdon, UK, 2015.

43. Gaudry, A.J.P. Insurgent Research. Wicazo Rev. 2011, 26, 113-136. [CrossRef]

44. Alfred, T.; Corntassel, J. Being Indigenous: Resurgences against Contemporary Colonialism. Gov. Oppos. 2005, 40, 597-614. [CrossRef]

45. Feit, H. Neo-Liberal Governance and James Bay Cree Governance: Negotiated Agreements, Oppositional Struggles, and CoGovernance. In Indigenous Peoples and Autonomy: Insights for a Global Age; UBC Press: Vancouver, Canada, 2010 ; pp. 49-79.

46. Alfred, T. Cultural Strength: Restoring the Place of Indigenous Knowledge in Practice and Policy. Aust. Aborig. Stud. 2015, 1, 3-11.

47. Simpson, L.B. As We Have Always Done: Indigenous Freedom through Radical Resistance; U of Minnesota Press: Minneapolis, MN, USA, 2017. 
48. Corntassel, J. Restorying Indigenous Landscapes: Community Regeneration and Resurgence. Plants, People, and Places: The Roles of Ethnobotany and Ethnoecology in Indigenous Peoples' Land Rights in Canada and Beyond; McGill-Queen's University Press: Montreal, CA, USA, 2020; pp. 350-361.

49. De Sousa Santos, B. The End of the Cognitive Empire: The Coming of Age of Epistemologies of the South; Duke University Press: Durham, NC, USA, 2018.

50. Lowitt, K.; Levkoe, C.Z.; Lauzon, R.; Ryan, K.; Sayers, C.D. Indigenous Self-Determination and Food Sovereignty through Fisheries Governance in the Great Lakes Region. In Civil Society and Social Movements in Food System Governance; Andrée, P., Clark, J.K., Levkoe, C.Z., Lowitt, K., Eds.; Routledge: Abigdon city, UK, 2019. [CrossRef]

51. Schlosberg, D. Defining Environmental Justice: Theories, Movements and Nature; Oxford University Press: Oxford, UK, 2007.

52. Schlosberg, D.; Collins, L.B.; Niemeyer, S. Adaptation Policy and Community Discourse: Risk, Vulnerability, and Just Transformation. Environmental Politics. Environ. Politics 2017, 26, 413-437. [CrossRef]

53. Fraser, N. Recognition without Ethics? Theory, Cult. Soc. 2001, 18, 21-42. [CrossRef]

54. Tsosie, R. Indigenous Peoples and Epistemic Injustice: Science, Ethics and Human Rights. Wash. Law Rev. 2012, 87, 1133-1201.

55. Brem-Wilson, J. Towards Food Sovereignty: Interrogating Peasant Voice in the United Nations Committee on World Food Security. J. Peasant. Stud. 2015, 42, 73-95. [CrossRef]

56. McKeon, N. Are Equity and Sustainability a Likely Outcome When Foxes and Chickens Share the Same Coop? Critiquing the Concept of Multistakeholder Governance of Food Security. Globalizations 2017, 14, 379-398. [CrossRef]

57. McKeon, N.; Berron, G. Introduction to 'Reclaiming Democracy from below: From the Contemporary State Capitalist System to Peoples' Sovereignty'. Globalizations 2020, 1-24. [CrossRef]

58. McTaggart, R. Reflection on the Purposes of Research, Action, and Scholarship: A Case of Cross-Cultural Participatory Action Research. Systemic Practice and Action Research 1999, 12, 493-511. [CrossRef]

59. Community-Based Participatory Research for Health: From Process to Outcomes; Minkler, M.; Wallerstein, N. (Eds.) John Wiley \& Sons: San Francisco, CA, USA, 2011.

60. Tondu, J.M.E.; Balasubramaniam, A.M.; Chavarie, L.; Gantner, N.; Knopp, J.A.; Provencher, J.F.; Wong, P.B.Y.; Simmons, D. Working with Northern Communities to Build Collaborative Research Partnerships: Perspectives from Early Career Researchers. Arctic 2014, 67. [CrossRef]

61. Spring, A.; Skinner, K.; Simba, M.; Nelson, E.; Baltzer, J.; Swanson, H.; Turetsky, M. Taking Care of the Land: An Interdisciplinary Approach to Community-Based Food Systems Assessment in Kakisa, Northwest Territories, Canada. In Sustainable Food System Assessment: Lessons from Global Practice; Blay-Palmer, A., Conaré, D., Meter, K., et al., Eds.; Routledge: London, UK, 2019; pp. 42-65. [CrossRef]

62. Spring, A.; Skinner, K.; Wesche, S.; Fresque-Baxter, J.; Brockington, M.; Bayha, G.; Dodd, W.; Dutton, J.; Fillion, M.; Kenny, T.-A.; et al. Building Community-University Research Partnerships to Enhance Capacity for Climate Change and Food Security Action in the NWT. North. Public Aff. 2020, 6, 63-67.

63. Bartlett, C.; Marshall, M.; Marshall, A. Two-Eyed Seeing and Other Lessons Learned within a Co-Learning Journey of Bringing Together Indigenous and Mainstream Knowledges and Ways of Knowing. J. Environ. Stud. 2012, 2, 331-340. [CrossRef]

64. Martin, D.H. Two-Eyed Seeing: A Framework for Understanding Indigenous and Non-Indigenous Approaches to Indigenous Health Research. Can. J. Nurs. Res. 2012, 44, 24.

65. Coen, D.; Pegram, T. Towards a Third Generation of Global Governance Scholarship. Glob. Policy 2018, 9, 107-113. [CrossRef]

66. Weiss, T.G.; Wilkinson, R. The Globally Governed-Everyday Global Governance. Global Governance 2018, 24, 193-210. [CrossRef]

67. Cameron, J.; Siegmann, K.A. Why Did Mainstream Economics Miss the Crisis? The Role of Epistemological and Methodological Blinkers. Horizon 2012, 20, 164-171. [CrossRef]

68. Duncan, J. Global Food Security Governance: Civil. Society Engagement in the Reformed Committee on World Food Security; Routledge: Abingdon, UK, 2015.

69. La Via Campesina. \#TimetoTransfom: Why do We Regard an Integral and Popular Agrarian Reform as a Matter of Urgency? Available online: https://viacampesina.org/en/timetotransform-why-do-we-regard-an-integral-and-popular-agrarian-reformas-a-matter-of-urgency / (accessed on 14 January 2021).

70. La Via Campesina. Declaration of the Forum for Food Sovereignty, Nyeleni 2007; La Via Campesina: Nyeleni, Mali, 2007.

71. Pimbert, M.P. Food Sovereignty, Agroecology and Biocultural Diversity: Constructing and Contesting Knowledge; Routledge: New York, NY, USA, 2018.

72. Desmarais, A.A.; Wittman, H. Farmers, Foodies and First Nations: Getting to Food Sovereignty in Canada. J. Peasant. Stud. 2014, 41, 1153-1173. [CrossRef]

73. McMichael, P. The Land Question in the Food Sovereignty Project. Globalizations 2015, 12, 434-451. [CrossRef]

74. Desmarais, A.A.; Nicholson, P. La Via Campesina: An Historical and Political Analysis. Available online: https://viacampesina. org/en/la-via-campesina-s-open-book-celebrating-20-years-of-struggle-and-hope/ (accessed on 14 January 2021).

75. Gaarde, I. Peasants Negotiating a Global Policy Space: La Via Campesina in the Committee on World Food Security; Routledge: Abingdon, UK, 2017.

76. Bayha, W. Barren-Ground Caribou Management in the Sahtu Region: Bridging Traditional Knowledge and Science. Rangifer 2012, 32, 37. [CrossRef]

77. Simba, M.; Spring, A. Growing a Garden in Kakisa. North. Public Aff. 2017, 5, 24-26. 
78. Dehcho First Nation. Negotiations. Available online: https:// dehcho.org/negotiations/ (accessed on 24 November 2020).

79. Government of Northwest Territories Executive and Indigenous Affairs. Concluding and Implementing Land Claim and SelfGovernment Agreements: Dehcho First Nations. Available online: https:/ /www.eia.gov.nt.ca/en/priorities/concluding-andimplementing-land-claim-and-self-government-agreements/dehcho-first (accessed on 24 November 2020).

80. Lowitt, K.; Levkoe, C.Z.; Spring, A.; Turlo, C.; Williams, P.L.; Bird, S.; Sayers, C.D.; Simba, M. Empowering Small-Scale, Community-Based Fisheries through a Food Systems Framework. Mar. Policy 2020, 120, 104150. [CrossRef]

81. Keck, M.E.; Sikkink, K. Activists Beyond Borders; Cornell University Press: Ithacam, NY, USA, 1998.

82. Bassano, D. The Bommerang Pattern: Verification and Modification. Peace Chang. 2014, 39, 23-48. [CrossRef]

83. Transnational Relations and World Politics; Keohane, R.; Nye, J. (Eds.) Harvard University Press: Cambridge, MA, USA, 1971.

84. Tarrow, S. The New Transnational Activism; Cambridge University Press: Cambridge, UK, 2005.

85. Gender Equality Norms in Regional Governance: Transnational Dynamics in Europe, South America and Southern Africa; Van der Vleuten, A.; van Eerdewijk, A.; Roggeband, C. (Eds.) Palgrave Macmillan: London, UK, 2014.

86. Szpak, A. Arctic Athabaskan Council's Petition to the Inter-American Commission on Human Rights and Climate ChangeBusiness as Usual or a Breakthrough? Clim. Chang. 2020, 162, 1575-1593. [CrossRef]

87. Thom, B. Leveraging International Power Private Property and the Human Rights of Indigenous Peoples in Canada. In Scales of Governance and Indigenous Peoples' Rights; Routledge: New York, NY, USA, 2019.

88. Reimerson, E. Between Nature and Culture: Exploring Space for Indigenous Agency in the Convention on Biological Diversity. Environ. Politics 2013, 22, 992-1009. [CrossRef]

89. Witter, R.; Suiseeya, K.R.M.; Gruby, R.L.; Hitchner, S.; Maclin, E.M.; Bourque, M.; Brosius, J.P. Moments of Influence in Global Environmental Governance. Environ. Politics 2015, 24, 894-912. [CrossRef]

90. UN Committee on World Food Security. Home. Available online: http:/ /www.fao.org/cfs/home/en/ (accessed on 14 January 2021).

91. Keating, N. Traversing the Scales of Rights: Interventions from Indigenous Peoples of Cambodia at the United Nations. In Scales of Governance and Indigenous Peoples' Rights; Routledge: New York, NY, USA, 2019.

92. Ford, J.; Maillet, M.; Pouliot, V.; Meredith, T.; Cavanaugh, A.; Lwasa, S.; Llanos, A.; Berrang-Ford, L.; Carcamo, C.; Namanya, D.B.; et al. Adaptation and Indigenous Peoples in the United Nations Framework Convention on Climate Change. Clim. Chang. 2016, 139, 429-443. [CrossRef]

93. Smith, H.A.; Sharp, K. Indigenous Climate Knowledges. WIREs Clim. Chang. 2012, 3, 467-476. [CrossRef]

94. Schroeder, H. Agency in International Climate Negotiations: The Case of Indigenous Peoples and Avoided Deforestation. Int. Environ. Agreem. 2010, 10, 317-332. [CrossRef]

95. Pictou, S. The Origins and Politics, Campaigns and Demands by the International Fisher Peoples' Movement: An Indigenous Perspective. Third World Q. 2018, 39, 1411-1420. [CrossRef]

96. Mooney, P. Policy Paper No 3- Blocking the Chain: Corporate Power and Big Data Platforms in the Global Food System; ETC Group, Glocon, Inkota \& Rosa-Luxemberg-Stiftung: Berlin, Germany, 2018.

97. Clapp, J. Mega-Mergers on the Menu: Corporate Concentration and the Politics of Sustainability in the Global Food System. Glob. Environ. Politics 2018, 18, 12-13. [CrossRef]

98. Clapp, J.; Scrinis, G. Big Food, Nutritionism, and Corporate Power. Globalizations 2017, 14, 578-595. [CrossRef]

99. Clapp, J.; Purugganan, J. Contextualizing Corporate Control in the Agrifood and Extractive Sectors. Globalizations 2020, 1-11. [CrossRef]

100. Franco, J.; Suárez, S.M. Why Wait for the State? Using the CFS Tenure Guidelines to Recalibrate Political-Legal Struggles for Democratic Land Control. Third World Q. 2018, 39, 1386-1402. [CrossRef]

101. Food and Agricultural Organization (FAO) of the United Nations. Voluntary Guidelines on the Responsible Governance of Tenure of Land, Fisheries and Forests in the Context of National Food Security; FAO: Rome, Italy, 2012.

102. Food and Agriculture Organization (FAO) of the United Nations; FoodFirst Information \& Action Network. Putting the Voluntary Guidelines on Tenure into Practice: A Learning Guide for Civil Society Organizations; FAO: Rome, Italy, 2017.

103. Jones, R.P. Liberals Introduce Bill to Implement UN Indigenous Rights Declaration. Available online: https:/ /www.cbc.ca/news / politics/liberals-introduce-undrip-legislation-1.5826523 (accessed on 10 December 2020).

104. Hannah, L.; Roehrdanz, P.R.; Krishna Bahadur, K.C.; Fraser, E.D.G.; Donatti, C.I.; Saenz, L.; Wright, T.M.; Hijmans, R.J.; Mulligan, M.; Berg, A.; et al. The Environmental Consequences of Climate-Driven Agricultural Frontiers. PLoS ONE 2020, 15, e0228305. [CrossRef] [PubMed]

105. Rocha, C.; Burlandy, L.; Maluf, R. Small Farms and Sustainable Rural Development for Food Security: The Brazilian Experience. Dev. South. Afr. 2012, 29, 519-529. [CrossRef]

106. Hanisch, A.L.; Negrelle, R.R.B.; Bonatto, R.A.; Nimmo, E.R.; Lacerda, A.E.B. Evaluating Sustainability in Traditional Silvopastoral Systems (Caívas): Looking beyond the Impact of Animals on Biodiversity. Sustainability 2019, 11, 3098. [CrossRef]

107. Lacerda, A.; Hanisch, A.L.; Nimmo, E. Leveraging Traditional Agroforestry Practices to Support Sustainable and Agrobiodiverse Landscapes in Southern Brazil. Land 2020, 9, 176. [CrossRef]

108. Nimmo, E.R.; Nogueira, J.F.M.M. Creating Hybrid Scientific Knowledge and Practice: The Jesuit and Guaraní Cultivation of Yerba Mate. Can. J. Lat. Am. Caribb. Stud. 2019, 44, 347-367. [CrossRef]

109. Nimmo, E.R.; de Carvalho, A.I.; Laverdi, R.; Lacerda, A.E.B. Oral History and Traditional Ecological Knowledge in Social Innovation and Smallholder Sovereignty: A Case Study of Erva-Mate in Southern Brazil. Ecol. Soc. 2020, 25, art17. [CrossRef] 
110. Vibrans, A.; McRoberts, R.; Lingner, D.; Nicoletti, A.; Moser, P. Extensão Original e Atual Da Cobertura Florestal de Santa Catarina. Inventár. Florístico Florest. St. Catarina 2012, 1, 65-76.

111. Ferrando, T.; Vispo, I.Á.; Anderson, M.; Dowllar, S.; Friedmann, H.; Gonzalez, A.; Maracle, C.; McKeon, N. Land, Territory and Commons: Voices and Visions from the Struggles. Globalizations 2020, 1-15. [CrossRef]

112. Gioia, P. Pathway to Resilience: Hands and Hearts for Peasant Livelihoods and Fair Relations between Humans and Nature. Third World Q. 2018, 39, 1403-1410. [CrossRef] 